\title{
PHYSICAL ACTIVITY OF UNIVERSITY STUDENTS AND ITS RELATION TO PHYSICAL FITNESS AND ACADEMIC SUCCESS
}

\author{
Silvester LIPOŠEK ${ }^{1}$, Jurij PLANINŠEC ${ }^{2}$, Bojan LESKOŠEK ${ }^{3}$, \\ Aleksander PAJTLER ${ }^{4}$ \\ ${ }^{1}$ University of Maribor, Faculty of Mechanical Engineering, Slovenia \\ ${ }^{2}$ University of Maribor, Faculty of Education, Slovenia \\ ${ }^{3}$ University of Ljubljana, Faculty of Sport, Slovenia \\ ${ }^{4}$ University of Maribor, Faculty of Civil Engineering, Transportation Engineering and \\ Architecture, Slovenia \\ Corresponding Author: \\ Silvester LIPOŠEK \\ University of Maribor, Faculty of Mechanical Engineering \\ Smetanova ulica 17, 2000 Maribor, Slovenia \\ Phone: +38631651868 \\ E-mail: silvester.liposek@um.si
}

\section{ABSTRACT}

Introduction: The purpose of this study was to determine the physical activity performed by students, its frequency and intensity and how this physical activity may relate to their physical fitness and academic success.

Methods: The sample consisted of 297 undergraduate students from 20 to 22 years of age (mean $20.5 \pm 0.7$ ) from the University of Maribor. The type and frequency of physical activity in which they engaged were measured using the IPAQ. Academic performance was defined as regular admission to the second year of study. Students 'physical fitness was determined using Eurofit and Fitness Gram tests.

Results: Analysis of the IPAQ questionnaire shows that the majority of students reported being physically active in the afternoon. Nevertheless, according to the WHO's guidelines, $79.8 \%$ of students were insufficiently physically active. The results show that males performed better than females in nearly all of the physical fitness tests. Periods of two to three hours of weekly physical activity were positively associated with academic success, while four hours or more resulted in no contribution.

Conclusion: Correlations between physical activity and physical fitness were primarily found in higher duration physical activity and in higher frequency of vigorous exercise. The results of this study are similar to those of other countries regarding the 
Silvester LIPOŠEK, Jurij PLANINŠEC, Bojan LESKOŠEK, Aleksander PAJTLER: PHYSICAL ACTIVITY OF UNIVERSITY STUDENTS ..., 89-104

insufficient physical activity of young people. The influence of physical activity on academic success was analyzed by binary logistic regression. The majority of students were academically successful and regularly admitted to the second year of study (86.5\%).

Keywords: physical activity, physical fitness, academic achievement, university students.

\section{TELESNA DEJAVNOST ŠTUDENTOV IN NJENA POVEZAVA S TELESNIM FITNESOM IN ŠTUDIJSKIM USPEHOM}

\section{IZVLE $\breve{C E K}$}

Namen: Cilj raziskave je bil ugotoviti pogostost in intenzivnost izvedene telesne aktivnosti študentov ter kako ta telesna aktivnost vpliva na njihovo telesno kondicijo in študijski uspeh.

Metode: V vzorec merjencev je bilo zajetih 297 dodiplomskih študentov in študentk

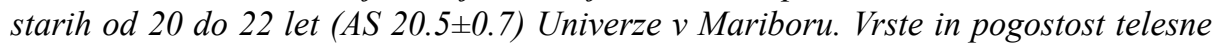
aktivnosti smo merili z IPAQ vprašalnikom. Akademska uspešnost študentov je bila ocenjena $z$ rednim napredovanjem $v$ drugi letnik študija. Telesna pripravljenost študentov je bila ocenjevana z uporabo Eurofit in Fitness Gram baterijo testov.

Rezultati: Rezultati analize IPAQ vprašalnika kažejo na to, da so študentje telesno aktivni večinoma v popoldanskih urah. V skladu s smernicami Svetovne zdravstvene organizacije (WHO) je kar 79,8\% študentov neaktivnih ali premalo telesno aktivnih. Rezultati nam kažejo, da moški v skoraj vseh testih telesne pripravljenosti dosegajo boljše rezultate kot ženske. Dve do tri ure telesne aktivnosti na teden kaže pozitiven učinek na študijski uspeh, medtem ko pri štirih urah in več tedenske aktivnosti, tega učinka ni zaznati.

Zaključek: Korelacija med telesno aktivnostjo in telesno kondicijo je bila ugotovljena predvsem ob daljšem trajanju telesne aktivnosti ter pogostosti naporne vadbe. Rezultati te študije so bili podobni študijam v drugih državah, kjer so ugotovili premajhno telesno aktivnost mladih. Vpliv telesne aktivnosti na študijski uspeh je bil analiziran z binarno logistično regresijo. Večina študentov je bila akademsko uspešnih $(86,5 \%)$ in je redno napredovala $v$ drugi letnik študija.

Ključne besede: ‘̌portna aktivnost, telesna pripravljenost, študijski uspeh, študenti. 
Silvester LIPOŠEK, Jurij PLANINŠEC, Bojan LESKOŠEK, Aleksander PAJTLER: PHYSICAL ACTIVITY OF UNIVERSITY STUDENTS ..., 89-104

\section{INTRODUCTION}

Past research studies confirm that regular physical activity performed by children, adolescents and adults has a positive effect on health (Boreham \& Roddoch, 2001; Pori et al., 2013) and reduces the risk of developing various diseases (Hallal, Victora, Azevedo \& Wells, 2006; Warburton, Nicol \& Bredin, 2006). Generally, physical fitness and physical activity excerpt a positive impact on perception and concentration (Centers for Disease Control and Prevention, 2010; Trudeau \& Shephard, 2008). Additionally, consistent physical activity has a positive influence on self-esteem (Crocker, Sabiston, Kowalski, McDonough \& Kowalski, 2006; Dunton, Jamner \& Cooper, 2003; Moreno, Cervelló \& Moreno, 2008; Weiss \& Williams, 2004), while lowering anxiety and stress (Dolenc, 2015; Flook, Repetti \& Ullman, 2005). However, it must be taken into account that vigorous physical activity is time-consuming, requires recovery and therefore might reduce learning and studying time. The extended use of the internet and computer games (i.e., screen-time) poses a huge threat to a healthy lifestyle; therefore, only a small proportion of adolescents regularly participate in physical activity (Aslan \& Arslan Cansever, 2012; Madell \& Muncer, 2004).

Many studies have attempted to identify a relationship between physical activity and academic achievement. However, these studies have had diverse and even contradictory conclusions: a significant positive correlation between the duration of physical activity and academic success (Coe, Pivarnik, Womack, Reeves \& Malina, 2006; Kim et al., 2003), small correlation between them (Daley \& Ryan, 2000; Sallis et al., 1999) and a negative correlation (Tremblay, Inman \& Williams, 2000). Research has also established that physical activity itself has many positive effects (better self-image, self-esteem, behavioural changes, better motivation in other areas, etc.), all of which influence academic success (Trudeau \& Shephard, 2008).

In the literature, the FitnessGram assessment was primarily used in the USA (Renfrow, Caputo, Otto, Farley \& Eveland-Sayers, 2011; Shriver et al., 2011). In Europe, for example, fitness tests were usually combined with FitnessGram and Eurofit items alongside some national recommendations (Aires et al., 2010). Recent results of health-related fitness tests on children show that results are progressively worsening and are accompanied by growing obesity and low physical activity (Shriver et al., 2011). A comparison between obesity and health-related fitness is easier to conduct because the measures are well-defined, whereas physical activity can be measured by various means, for example, by weekly duration, frequency, intensity or variety.

The study of physical activity of the university student population is especially interesting, as in Slovenia and several other countries (Cardinal, Sorensen \& Cardinal, 2012; Hardman, 2008), physical education is no longer a mandatory subject at tertiary level, as it is in secondary schools. Therefore, it is important to establish if one of the most important objectives of mandatory physical education, i.e., educating students to accept physical activity as one of their regular life-long habits, has actually been fulfilled and if the decision to drop physical education from university curricula, a decision 
Silvester LIPOŠEK, Jurij PLANINŠEC, Bojan LESKOŠEK, Aleksander PAJTLER: PHYSICAL ACTIVITY OF UNIVERSITY STUDENTS ..., 89-104

made several years ago, has resulted in a large proportion of students becoming insufficiently active or even inactive.

The aim of our study was twofold: 1) to explore the current state of physical activity and the physical fitness of university students and their anthropometric data and 2) to explore the relationship between physical activity, physical fitness and the academic success of university students. There has been little research on the effect of physical activity on academic performance in Slovenia. On the basis of research results elsewhere, we assume that our study will demonstrate the positive effects of physical activity on academic performance.

\section{METHODS}

\section{Sample}

The sample consisted of second-year undergraduate students from fourteen faculties of the University of Maribor. Approximately $10 \%$ of all full-time second-year undergraduate students, between 20 and 22 (mean $20.5 \pm 0.7$ ) years of age, agreed to participate in the study $(\mathrm{n}=297,114$ or $38.4 \%$ males and 183 or $61.6 \%$ females $)$.

\section{Data Collection Procedure}

To collect information about students' physical activities in the week before fitness testing, we used the IPAQ questionnaire (Bailey, Mckay, Mirwald, Crocker \& Faulkner, 1999) with certain modifications (questions about the time of day and the type of physical activities were added). The time aspect of physical activity execution is divided as follows: pre-noon physical activities happen before 12 o'clock, afternoon physical activities are performed between 12 and $6 \mathrm{pm}$, while evening physical activities are executed after $6 \mathrm{pm}$ and later. Physical fitness testing took place at the University Sports Centre and was carried out by staff trained in measurement procedures. The two-day testing was open to all second-year students at the University of Maribor. Participation was voluntary; all of the participants gave written consent. Individual fitness tests were carried out at stations set up as a polygon. The order of fitness tests and conducted measurements were the same for all participants. We administered the following twelve physical fitness test items to measure motor performance FitnessGram (Meredith \& Welk, 2010), EuroFit (Topend Sports, 2016) and national recommendations SLOFit (Strel et al., 1996): plate tapping test (20"), polygon backwards, the wall toss test, standing forward bend and reach flexibility test, sit and reach flexibility test, standing shoulder rotation flexibility test, standing long jump test, sit-ups in 60" test, flexed arm hang test, the flamingo balance test, 20 -meter sprint and the 20 -meter shuttle run. The 20-meter shuttle run results were converted to VO2 max volumes according to the instructions set out by Ramsbottom et al. (1988). The following anthropometric measures 
Silvester LIPOŠEK, Jurij PLANINŠEC, Bojan LESKOŠEK, Aleksander PAJTLER: PHYSICAL ACTIVITY OF UNIVERSITY STUDENTS ..., 89-104

were taken (Topend Sports, 2016): body height, body weight, upper arm circumference, thigh circumference and abdominal circumference. To estimate the amount of subcutaneous fat, we measured each participant's upper arm (triceps) skinfold, thigh skinfold (suprapatellar), abdomen skinfold (abdominal and suprailiac skinfold) and back skinfold.

The weekly duration of physical activity (number of hours of physical activity in the previous week), frequency of vigorous physical activity (number of sessions of vigorous physical activity lasting at least 15 minutes in the previous week), frequency of moderate physical activity (number of sessions of moderate physical activity lasting at least 15 minutes in the previous week), frequency of low effort physical activity (number of sessions of low effort physical activity lasting at least 15 minutes in the previous week) and sports club membership were used as indicators of physical activity. Criteria suggested by Janssen (2001) were employed to measure the intensity of physical activity (vigorous, moderate, low effort).

The dependent variable of academic success was defined as the regular admission to the second year of study (coded as 1 if a student was regularly admitted from the first to the second year of study and 0 otherwise).

\section{Data Analysis}

The collected data were analyzed using IBM SPSS 20.0 software (IBM Corp., Armonk, NY). Physical fitness test results were compared by gender using an independent samples t-test or Mann-Whitney U test in case the Shapiro-Wilks test did not confirm the normal distribution of data. To determine the relationship between physical activity and physical fitness tests, Spearman's correlation coefficient was used. The influence of physical activity on academic success was calculated by a binary logistic regression. The odds ratio, $95 \%$ confidence interval and $P$ value were calculated for each variable included in the logistic model. A $P<0.05$ was considered statistically significant.

\section{RESULTS}

Analysis of the IPAQ questionnaire results shows that the majority of students reported being physically active in the afternoon (from 12 to $6 \mathrm{pm})$, as $161(54.2 \%)$ reported being active 2 to 3 times a week or more; in the evening (after $6 \mathrm{pm}$ ), this figure was 94 (31.6\%), and in the morning (before noon), 43 (14.5\%) reported being physically active. Eleven (3.7\%) students were completely inactive during the previous week. Figure 1 also shows that males and females reported a similar physical activity pattern during the week. 

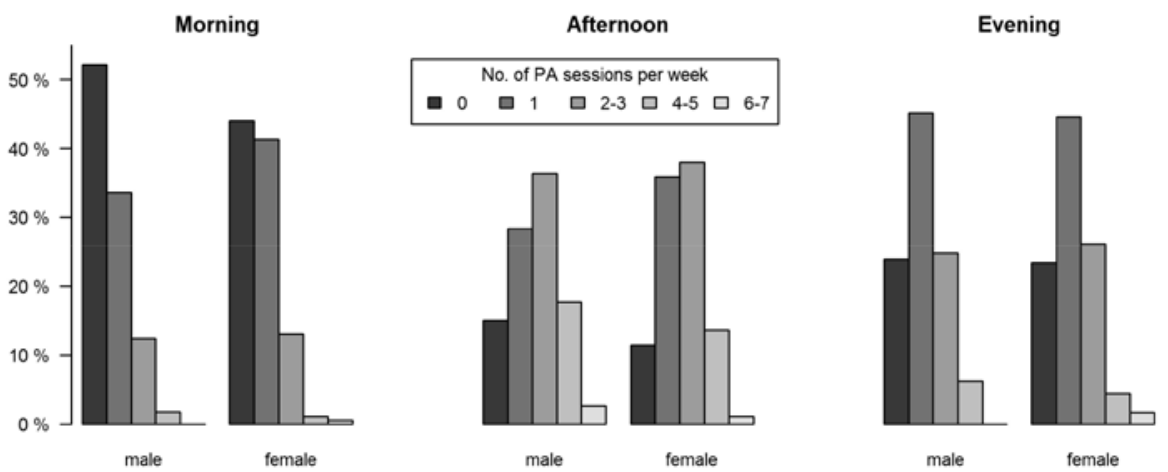

Figure 1. Weekly Frequency of Physical Activity of Students by Gender and Time of Day.

For vigorous exercise of at least 15 minutes, 79 (26.6\%) students reported no engagement, and $82(27.6 \%)$ students exercised vigorously only once a week. For moderate exercise of at least 15 minutes, 106 (35.7\%) students reported exercising once a week, while $62(20.9 \%)$ reported never exercising at this intensity level. $78(26.3 \%)$ students engaged in exercises requiring low effort once a week, while 94 (31.6\%) students reported no engagement (Figure 2). Based on the criteria set forth in the WHO's guidelines (WHO, 2004), 237 (79.8 \%) students were inactive or insufficiently active because they were not physically active for at least 150 minutes of moderate-intensity, or at least 75 minutes of vigorous-intensity, exercise throughout the week. Among these students, approximately half expressed a lack of free time and being overburdened with study as the reasons for their inactivity.
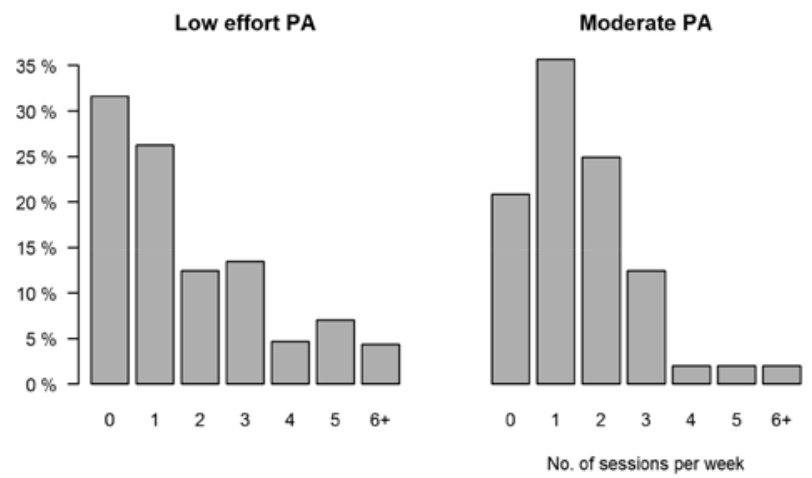

Vigorous PA

Figure 2. Frequency of Weekly Physical Activity (PA) Lasting Longer Than 15 Minutes. 
Silvester LIPOŠEK, Jurij PLANINŠEC, Bojan LESKOŠEK, Aleksander PAJTLER: PHYSICAL ACTIVITY OF UNIVERSITY STUDENTS ..., 89-104

The anthropometric data results in Table 1 show that male students were higher, heavier and had a higher body mass index. Males also had larger circumferences and lower skinfolds with the exception of the abdominal skinfold. There were also no differences in age between the groups.

Table 1. Anthropometric data arranged by gender of students.

\begin{tabular}{|l|c|c|c|c|c|}
\hline & \multicolumn{2}{|c|}{ Males } & \multicolumn{2}{c|}{$\begin{array}{c}\text { Females } \\
\text { n=183 }\end{array}$} & p-value* \\
\hline & mean & SD & mean & SD & \\
\hline Age (years) & 20.4 & 0.7 & 20.5 & 0.7 & ns \\
\hline Body height (cm) & 180.7 & 6.7 & 166.2 & 5.9 & $<0.001$ \\
\hline Body weight (kg) & 80.0 & 10.5 & 64.0 & 12.3 & $<0.001$ \\
\hline Body mass index (kg/m2) & 24.5 & 3.0 & 23.1 & 4.3 & $<0.001$ \\
\hline Upper arm circumference (mm) & 305.1 & 27.7 & 272.8 & 34.5 & $<0.001$ \\
\hline Thigh circumference (mm) & 576.1 & 44.8 & 558.9 & 60.5 & 0.006 \\
\hline Abdominal circumference (mm) & 871.7 & 83.7 & 824.5 & 119.4 & $<0.001$ \\
\hline Upper arm skinfold (mm) & 10.5 & 4.9 & 17.0 & 8.0 & $<0.001 \#$ \\
\hline Back skinfold (mm) & 13.9 & 5.8 & 16.3 & 8.9 & $0.006 \#$ \\
\hline Thigh skinfold (mm) & 18.0 & 9.0 & 24.3 & 8.7 & $<0.001 \#$ \\
\hline Abdominal skinfold (mm) & 18.7 & 8.5 & 19.2 & 8.4 & $\mathrm{~ns} \#$ \\
\hline Suprailiac skinfold (mm) & 17.4 & 8.2 & 20.4 & 7.9 & $0.002 \#$ \\
\hline
\end{tabular}

* independent samples t-test; \# Mann-Whitney U test; ns = not significant

The results in Table 2 show that males performed statistically significantly better than females in most of the twelve physical fitness tests, except in three flexibility tests (Standing forward bend and reach, Sit and reach, Shoulder rotation), where female students performed better than males and in Flamingo balance test where the difference is not significant. 
Silvester LIPOŠEK, Jurij PLANINŠEC, Bojan LESKOŠEK, Aleksander PAJTLER: PHYSICAL ACTIVITY OF UNIVERSITY STUDENTS ..., 89-104

Table 2. Physical fitness test results arranged by gender.

\begin{tabular}{|l|c|c|c|c|c|}
\hline & \multicolumn{2}{|c|}{$\begin{array}{c}\text { Males } \\
\text { n=114 }\end{array}$} & \multicolumn{2}{c|}{$\begin{array}{c}\text { Females } \\
\text { n=183 }\end{array}$} & $\begin{array}{c}\text { p-va- } \\
\text { lue* }\end{array}$ \\
\hline Plate tapping 20« (count) & 48.9 & 4.9 & 46.2 & 4.7 & $<0.001$ \\
\hline Polygon backwards (seconds) & 9.0 & 1.6 & 11.9 & 2.2 & $<0.001$ \\
\hline Wall toss test (count) & 22.9 & 4.9 & 15.9 & 4.7 & $<0.001$ \\
\hline Standing forward bend and reach (cm) & 46.6 & 7.8 & 49.7 & 7.3 & 0.001 \\
\hline Sit and reach (cm) & 22.6 & 7.9 & 26.6 & 7.3 & $<0.001$ \\
\hline Shoulder rotation (cm) & 109.4 & 15.5 & 88.5 & 16.7 & $<0.001$ \\
\hline Standing long jump (cm) & 225.9 & 24.1 & 161.8 & 22.5 & $<0.001$ \\
\hline Sit-ups 60" (count) & 49.8 & 9.2 & 41.1 & 9.1 & $<0.001$ \\
\hline Flexed arm hang test (seconds) & 24.6 & 17.0 & 11.5 & 13.6 & $<0.001 \#$ \\
\hline Flamingo balance test (count) & 9.3 & 5.0 & 9.7 & 4.7 & $\mathrm{~ns} \#$ \\
\hline 20-m sprint (seconds) & 3.2 & 0.2 & 4.1 & 0.4 & $<0.001$ \\
\hline 20-m shuttle run (VO2 max, ml/kg/min) & 38.2 & 6.4 & 27.4 & 1.4 & $<0.001$ \\
\hline
\end{tabular}

$\mathrm{M}=$ mean; $\mathrm{SD}=$ standard deviation; * independent samples t-test; \# Mann-Whitney $\mathrm{U}$ test; ns $=$ not significant

To find out how physical activity correlates with physical fitness, we analyzed three different parameters describing the extent of physical activity: a) weekly duration of physical activity; b) the weekly frequency of vigorous exercise lasting at least $15 \mathrm{mi}$ nutes and c) weekly frequency of moderate exercise lasting at least 15 minutes. As the significant differences between males and females in physical fitness were found, we decided to analyze this relation separately, by gender. The results in Table 3 provided several significant relationships between the duration and intensity of physical activity and fitness with primarily weak correlation coefficients. 
Silvester LIPOŠEK, Jurij PLANINŠEC, Bojan LESKOŠEK, Aleksander PAJTLER: PHYSICAL ACTIVITY OF UNIVERSITY STUDENTS ..., 89-104

Table 3. Correlation between Physical Activity and Physical Fitness Test Results, Arranged by Gender.

\begin{tabular}{|c|c|c|c|c|c|c|}
\hline & \multicolumn{2}{|c|}{$\begin{array}{c}\text { weekly duration of } \\
\text { physical activity in } \\
\text { hours }\end{array}$} & \multicolumn{2}{|c|}{$\begin{array}{l}\text { weekly frequency of } \\
\text { vigorous exercise la- } \\
\text { sting at least } 15 \text { min }\end{array}$} & \multicolumn{2}{|c|}{$\begin{array}{l}\text { weekly frequency of } \\
\text { moderate exercise la- } \\
\text { sting at least } 15 \mathrm{~min}\end{array}$} \\
\hline & $\begin{array}{c}\text { Males } \\
\mathbf{n}=114 \\
\mathbf{r} * *\end{array}$ & $\begin{array}{c}\text { Females } \\
\begin{array}{c}n=183 \\
r *\end{array}\end{array}$ & $\begin{array}{c}\text { Males } \\
\mathrm{n}=114 \\
\mathbf{r}^{* *}\end{array}$ & $\begin{array}{c}\text { Females } \\
\mathbf{n}=183 \\
\mathbf{r}^{* *}\end{array}$ & $\begin{array}{c}\text { Males } \\
\mathbf{n}=114 \\
\mathbf{r}^{* *}\end{array}$ & $\begin{array}{c}\text { Females } \\
\mathbf{n}=183 \\
\mathbf{r} * *\end{array}$ \\
\hline Plate tapping & $0.20 \#$ & 0.11 & $0.26^{*}$ & 0.13 & -0.12 & -0.03 \\
\hline Polygon backwards & -0.14 & $-0.15 \#$ & $-0.19 \#$ & $-0.18 \#$ & 0.08 & 0.04 \\
\hline Wall toss test & $0.36^{*}$ & $0.17 \#$ & $0.28 *$ & 0.12 & 0.18 & -0.09 \\
\hline $\begin{array}{l}\text { Standing forward } \\
\text { bend and reach }\end{array}$ & 0.11 & $0.15 \#$ & 0.02 & 0.14 & 0.00 & 0.04 \\
\hline Sit and reach & 0.13 & 0.13 & -0.04 & 0.04 & 0.11 & 0.06 \\
\hline Shoulder rotation & -0.03 & 0.00 & 0.00 & -0.10 & 0.13 & -0.10 \\
\hline Standing long jump & $0.21 \#$ & 0.14 & $0.26^{*}$ & $0.19 *$ & -0.03 & -0.01 \\
\hline Pull-up 60" & $0.24 *$ & $0.17 \#$ & $0.32 *$ & $0.21 *$ & -0.05 & 0.11 \\
\hline Flexed arm hang test & $0.25 *$ & $0.30 *$ & $0.25^{*}$ & $0.23 *$ & 0.11 & $0.21 *$ \\
\hline $\begin{array}{l}\text { Flamingo balance } \\
\text { test }\end{array}$ & $-0.20 \#$ & -0.10 & -0.14 & $-0.19^{*}$ & 0.05 & 0.02 \\
\hline 20-m sprint & -0.06 & $-0.22 *$ & -0.14 & $-0.22 *$ & 0.02 & -0.08 \\
\hline 20-m shuttle run & $0.29 *$ & $0.23 *$ & $0.37 *$ & $0.28 *$ & -0.01 & 0.00 \\
\hline
\end{tabular}

$\mathrm{r}^{* *}=$ Spearman's correlation coefficient; $*=\mathrm{p}<0.001 ; \#=\mathrm{p}<0.05$

The influence of physical activity on academic success was analyzed by binary logistic regression (Table 4). The majority of students were academically successful and regularly admitted to the second year of study $(86.5 \mathrm{n} \%)$. Two or three hours of weekly physical activity had a positive influence on regular admission to the second year of study $(\mathrm{OR}=3.37,95 \%, \mathrm{CI}=1.18-9.62, P=0.024$ and $\mathrm{OR}=4.37,95 \% \mathrm{CI}=1.44-13.24$, $P=0.009$, respectively). Neither vigorous physical activity nor sports club membership had any influence on academic success $(\mathrm{OR}=0.55,95 \% \mathrm{CI}=0.21-1.43, P=0.220$ and $\mathrm{OR}=0.81,95 \% \mathrm{CI}=0.30-2.18, P=0.674$, respectively). Regarding the anthropome- 
Silvester LIPOŠEK, Jurij PLANINŠEC, Bojan LESKOŠEK, Aleksander PAJTLER: PHYSICAL ACTIVITY OF UNIVERSITY STUDENTS ..., 89-104

tric data, being overweight (as indicated by body mass index) also had no influence on academic success $(\mathrm{OR}=0.72,95 \% \mathrm{CI}=0.31-1.69, P=0.452)$.

Table 4. Binary logistic regression for the prediction of academic success.

\begin{tabular}{|c|c|c|c|c|}
\hline & \multicolumn{2}{|c|}{$\begin{array}{l}\text { Regular admission to the } \\
\text { 2nd year of study }\end{array}$} & \multirow[t]{2}{*}{ OR $(95 \%$ CI $)$} & \multirow[t]{2}{*}{ p-value } \\
\hline & $\begin{array}{c}\text { No } \\
n=40(\%)\end{array}$ & $\begin{array}{c}\text { Yes } \\
\mathbf{n}=\mathbf{2 5 7}(\%)\end{array}$ & & \\
\hline \multicolumn{5}{|l|}{ Weekly PA } \\
\hline 1 hour or less & $11(27.5)$ & $30(11.7)$ & 1.00 (reference) & \\
\hline 2 hours & $8(20.0)$ & $64(24.9)$ & $3.37(1.18-9.62)$ & 0.024 \\
\hline 3 hours & $7(17.5)$ & $75(29.2)$ & $4.37(1.44-13.24)$ & 0.009 \\
\hline 4 hours & $5(12.5)$ & $37(14.4)$ & $3.54(0.99-12.59)$ & 0.051 \\
\hline 5 hours or more & $9(22.5)$ & $51(19.8)$ & $3.26(0.86-12.45)$ & 0.083 \\
\hline \multicolumn{5}{|l|}{ Vigorous PA } \\
\hline $2 \mathrm{x}$ weekly or less & $28(70.0)$ & $199(77.4)$ & 1.00 (reference) & \\
\hline $3 \mathrm{x}$ weekly or more & $12(30.0)$ & $58(22.6)$ & $0.55(0.21-1.43)$ & 0.220 \\
\hline \multicolumn{5}{|l|}{ Moderate PA } \\
\hline $2 \mathrm{x}$ weekly or less & $34(85.0)$ & $208(80.9)$ & 1.00 (reference) & \\
\hline $3 \mathrm{x}$ weekly or more & $6(15.0)$ & $49(19.1)$ & $1.09(0.38-3.11)$ & 0.875 \\
\hline \multicolumn{5}{|l|}{ Low effort PA } \\
\hline $2 \mathrm{x}$ weekly or less & $31(77.5)$ & $179(69.6)$ & 1.00 (reference) & \\
\hline $3 \mathrm{x}$ weekly or more & $9(22.5)$ & $78(30.4)$ & $1.18(0.51-2.76)$ & 0.700 \\
\hline \multicolumn{5}{|c|}{ Sports club membership } \\
\hline No & $30(75.0)$ & $206(80.2)$ & 1.00 (reference) & \\
\hline Yes & $10(25.0)$ & $51(19.8)$ & $0.81(0.30-2.18)$ & 0.674 \\
\hline \multicolumn{5}{|l|}{ Body mass index } \\
\hline$<25$ (normal) & $27(67.5)$ & $187(72.8)$ & 1.00 (reference) & \\
\hline$\geq 25$ (overweight) & $9(22.5)$ & $51(19.8)$ & $0.72(0.31-1.69)$ & 0.452 \\
\hline$\geq 30$ (obese) & $4(10.0)$ & $19(7.4)$ & $0.56(0.17-1.88)$ & 0.349 \\
\hline \multicolumn{5}{|l|}{ Gender } \\
\hline Male & $16(40.0)$ & $98(38.1)$ & 1.00 (reference) & \\
\hline Female & $24(60.0)$ & $159(61.9)$ & $0.94(0.43-2.03)$ & 0.868 \\
\hline
\end{tabular}

$\mathrm{OR}=$ odds ratio, $95 \% \mathrm{CI}=95 \%$ confidence interval, $\mathrm{PA}=$ physical activity 
Silvester LIPOŠEK, Jurij PLANINŠEC, Bojan LESKOŠEK, Aleksander PAJTLER: PHYSICAL ACTIVITY OF UNIVERSITY STUDENTS ..., 89-104

\section{DISCUSSION}

International studies have shown that the percentage of physically inactive students varies from country to country: $23 \%$ in Western Europe and the U.S., $30 \%$ in Central and Eastern Europe, $39 \%$ in Mediterranean countries, $42 \%$ in the countries of the Asia-Pacific region and $44 \%$ in developing countries (Haase, Steptoe, Sallis \& Wardle, 2004). Guthold published data on levels of physical inactivity in 51 countries, most of which were low or middle income, and observed several trends (Guthold, Ono, Strong, Chatterji, \& Morabia, 2008). Globally, with the exception of several Eastern European countries, women were more likely to be physically inactive than men. Few studies have explored the reasons for decreasing levels of physical activity in developing countries. $\mathrm{Ng}$ et al. (2009) estimate that between 1991 and 2006, average weekly physical activity fell by 32 per cent. Globally, around $23 \%$ of adults aged 18 and over were not active enough in 2010 (men $20 \%$ and women $27 \%$ ). In high-income countries, $26 \%$ of men and $35 \%$ of women were insufficiently physically active, as compared to $12 \%$ of men and $24 \%$ of women in low-income countries (World Health Organization, 2016).

The results of our study showed a more positive picture as only $7.4 \%$ of students reported not being involved in vigorous or moderate exercise; however, $26.6 \%$ of students reported not performing any vigorous exercise. The results of our study on the physical activity of students may therefore be considered similar to previous studies. With respect to the WHO recommendations (World Health Organization, 2004), with the time component of adequate physical activity included (150 minutes of moderate-intensity, or at least 75 minutes of vigorous-intensity throughout the week), our results are worse, showing that only $20.2 \%$ of students reported adequate physical activity. For example, this percentage was similar to a national survey conducted by Caspersen, Fereira, and Curran (2000), who found that only $25 \%$ of Americans reach the recommended level of physical activity. Regarding organized physical activity, our study showed that only $20.5 \%$ of the students were active in a sports club. The percentage of students active in sports clubs is close to the figure in Croatia (23\%) (Andrijašević, Paušić, Bavčević \& Ciliga, 2005), although another study has suggested that only $16 \%$ of Slovene students are actually active in sports clubs (Golja \& Robič, 2014).

In Sweden, however, it was reported that the percentage of young people engaged in sport clubs is increasing, as $66 \%$ of boys and $53 \%$ of girls were active in them (Westerståhl, Barnekow-Berkvist, Hedberg \& Jansson, 2003), a percentage that is considerably higher than the levels in Slovenia or Croatia. Our results showed that students were under-active, considering that a healthy adult requires a minimum physical activity time of at least 150 minutes of moderate exercise per week (such as fast walking, cycling on flat terrain, or even mowing the lawn) or 75 minutes of vigorous exercise (running, swimming, rough terrain biking, playing basketball or tennis) (Janssen, 2001), where only approximately $20.2 \%$ of students reported sufficiently frequent engagement.

Since the results of the physical fitness tests indicated significant differences between males and females, we decided to calculate the correlation between physical activity and fitness tests results by gender. The results show that in this gender comparison, 
Silvester LIPOŠEK, Jurij PLANINŠEC, Bojan LESKOŠEK, Aleksander PAJTLER: PHYSICAL ACTIVITY OF UNIVERSITY STUDENTS ..., 89-104

there is on average a smaller share of women who take part in no physical activity, but a higher percentage who take part in physical activity once or two to three times per week. The study demonstrates that male students outperformed their female counterparts in almost all motor tests except the flamingo, which measures balance, where no significant difference was found and in flexibility, where female students performed better than male.

The second purpose of the study was to explore the relationship between the reported extent of weekly physical activity and physical fitness. In most cases, especially in overall weekly duration of physical activity and weekly frequency of vigorous exercise lasting at least 15 minutes, physical activity is positively correlated to physical fitness, however most correlation coefficients were low and, in some cases, also not statistically significant. Even weaker correlation was found between weekly frequency of moderate exercise lasting at least 15 minutes and physical fitness. The only coefficients exceeding 0.3 were those between overall duration of physical activity and the frequency of vigorous exercise with the wall toss test, pull-up 60" and 20-m shuttle run among male students. Similarly, Renfrow et al. (2011) found that males who played more sports achieved significantly better FitnessGram overall scores. In a longitudinal study, Aires et al. (2010) found that an increased physical activity index contributed to improved physical fitness. Associations between physical activity and physical fitness tests, as documented in available studies such as Martinez-Vizcaino \& Sanchez-Lopez, (2008), Fang et al. (2017) show the positive effects of increased physical activity for improved health-related physical fitness in children and young people (Martínez-Vizcaíno \& Sánchez-López, 2008; Malina, Bouchard \& Bar-Or, 2004).

Our last research aim was to explore whether the extent of physical activity influences academic success, which was defined as regular admission from the first to the second year of study. In previous researches, physical activity has not clearly been associated with academic performance (Daley \& Ryan, 2000; Sallis et al., 1999; Tremblay et al., 2000). Our results provided some evidence that higher duration of physical activity may positively influence academic performance, which was similar to Coe et al. (2006), Kim et al. (2003) California Department of Education (2001), Sibley \& Eitner (2003), Castelli, Hillman, Buck \& Erwin (2007) and Trost (2016). On the other hand, our results regarding comprehensive vigorous physical activity or sports club membership provided no proof of their positive influence on academic success. This might suggest that two to three hour weekly recreational physical activity is positive for one's academic success, while sporting physical activity is probably too exhausting and time- consuming.

\section{Study Limitations}

Measuring weekly physical activity among the population is difficult because its duration, intensity, frequency, and type of exercise performed are seldom recorded. Physical activity is usually performed with less consistency, more often in some weeks, in others less, sometimes physical activity is performed on weekends, sometimes 
Silvester LIPOŠEK, Jurij PLANINŠEC, Bojan LESKOŠEK, Aleksander PAJTLER: PHYSICAL ACTIVITY OF UNIVERSITY STUDENTS ..., 89-104

during the week, etc. Therefore, participants face difficulties in reliability and reporting every detail of their weekly physical activity. To reduce bias, we gathered data about physical activity with several measures: weekly duration in hours, frequency by intensity of exercise (vigorous and moderate), larger sample, the greater number of faculties and different level of exercise (low effort PA, moderate PA, vigorous PA).

\section{CONCLUSIONS}

This study indicates that the duration of physical activity has only a limited influence on the academic performance of undergraduate students. Two to three hour weekly recreational physical activity proved beneficial, while comprehensive vigorous exercise and sports club participation did not. According to the literature, we expected stronger correlations between the reported extent of weekly physical activity and fitness test performance. Similarly, we did not expect such negative / bad results about the extent of physical activity among students, as they in general reported physical activity below international recommendations. In Slovenia, the number of physically active students would most certainly increase if each faculty had adequate sports facilities and equipment which students could use in their leisure time free of charge.

Both society in general and individuals can take action to increase physical activity. In 2013, WHO Member States agreed to a target of reducing insufficient physical activity by $10 \%$ by 2025 and included strategies to achieve this goal in the „Global Action Plan for the Prevention and Control of Non-communicable Diseases 2013-2020“. Slovenia should also adhere to this action plan.

\section{FUNDING}

The study had no accessional financial support.

\section{ETHICAL APPROVAL}

Written informed consent was obtained from all tested students

\section{REFERENCES}

Andrijašević, A., Paušić, J., Bavčević, T., \& Ciliga, D. (2005). Participation in leisure activities and self-perception of health in the students of the University of Split. Kinesiology, 37(1), 21-31. VIEW ITEM

Aires, L., Andersen, L. B., Mendonca, D., Martins, C., Silva, G., \& Mota, J. (2010). A 3 -year longitudinal analysis of changes in fitness, physical activity, fatness and screen 
Silvester LIPOŠEK, Jurij PLANINŠEC, Bojan LESKOŠEK, Aleksander PAJTLER: PHYSICAL ACTIVITY OF UNIVERSITY STUDENTS ..., 89-104

time. Acta Paediatrica, 99(1), 140-144. doi: 10.1111/j.1651-2227.2009.01536.x. VIEW ITEM

Aslan, N., \& Arslan Cansever, B. (2012). Leisure perceptions of adolescents. Hacettepe University Journal of Education, 42, 23-35. VIEW ITEM

Bailey, D. A., Mckay, H. A., Mirwald, R. L., Crocker, P. R. E., \& Faulkner, R. A. (1999). A six-year longitudinal study of the relationship of physical activity to bone mineral accrual in growing children: The University of Saskatchewan bone mineral accrual study. Journal of Bone and Mineral Research, 14(10), 1672-1679. doi: 10.1359/ jbmr.1999.14.10.1672 VIEW ITEM

Boreham, C., \& Riddoch, C. (2001). The physical activity, fitness and health of children. Journal of Sports Sciences, 19(12), 915-929. doi: 10.1080/026404101317108426 VIEW ITEM

California Department of Education CDE. (2001). California physical fitness test: Report to the governor and legislature. Sacramento, CA: California Department of Education Standards and Assessment Division.

Cardinal, B. J., Sorensen, S. D., \& Cardinal, M. K. (2012). Historical perspective and current status of the physical education graduation requirement at American 4-year colleges and universities. Research Quarterly for Exercise and Sport, 83(4), 503-512. doi: 10.1080/02701367.2012.10599139 VIEW ITEM

Caspersen, C. J., Pereira, M. A., \& Curran, K. M. (2000). Changes in physical activity patterns in the United States, by sex and cross-sectional age. Medicine and Science in Sports and Exercise, 32(9), 1601-1609. VIEW ITEM

Castelli, D. M., Hillman, C. H., Buck, S. M., \& Erwin, H. E. (2007). Physical fitness and academic achievement in third- and fifth-grade students. Journal of Sport and Exercise Psychology, 29(2), 239-252. doi: 10.1123/jsep.29.2.239 VIEW ITEM

Centers for Disease Control and Prevention (2010). The association between school based physical activity, including physical education, and academic performance. Retrieved from https://www.cdc.gov/healthyyouth/health and academics/pdf/pa-pe paper.pdf.

Coe, D. P., Pivarnik, J. M., Womack, C. J., Reeves, M. J., \& Malina, R. M. (2006). Effect of physical education and activity levels on academic achievement in children. Medicine and Science in Sports and Exercise, 38(8), 1515-1519. doi: 10.1249/01. mss.0000227537.13175.1b VIEW ITEM

Crocker, P. R. E., Sabiston, C. M., Kowalski, K. C., McDonough, M. H., \& Kowalski N. (2006). Longitudinal assessment of the relationship between physical self-concept and health-related behavior and emotion in adolescent girls. Journal of Applied Sport Psychology, 18(3), 185-200. doi: 10.1080/10413200600830257 VIEW ITEM

Daley, A. J., \& Ryan, J. (2000) Academic performance and participation in physical activity by secondary adolescents. Perceptual and Motor Skills, 91(2), 531-534. doi: 10.2466/ pms.2000.91.2.531 VIEW ITEM

Dolenc, P. (2015). Anxiety, self-esteem and coping with stress in secondary school students in relation to involvement in organized sports. Zdravstveno varstvo, 54(3), 222-229. doi: 10.1515/sjph-2015-0031 VIEW ITEM

Dunton, G. F., Jamner, M. S., \& Cooper, D. M. (2003). Physical self-concept in adolescent girls: Behavioral and physiological correlates. Research quarterly for Exercise and Sport, 74(3), 360-365. doi: 10.1080/02701367.2003.10609104 VIEW ITEM 
Silvester LIPOŠEK, Jurij PLANINŠEC, Bojan LESKOŠEK, Aleksander PAJTLER: PHYSICAL ACTIVITY OF UNIVERSITY STUDENTS ..., 89-104

Fang, H., Quan, M., Zhou, T., Sun, S., Zhang, J., Zhang, H., \& et al. (2017). Relationship between physical activity and physical fitness in preschool children: a cross-sectional study. BioMed Research International. doi: 10.1155/2017/9314026 VIEW ITEM

Flook, L., Repetti, R. L., \& Ullman, J. B. (2005). Classroom social experiences as predictors of academic performance. Developmental Psychology, 41(2), 319-327. doi: 10.1037/0012-1649.41.2.319 VIEW ITEM

Golja, P., \& Robič, T. (2014). The role of sports clubs in sports activity of students. Zdravstveno varstvo, 53(1), 26-33. doi: 10.1515/sjph-2014-0004 VIEW ITEM

Guthold, R., Ono, T., Strong, K. L., Chatterji, S., \& Morabia, A. (2008). Worldwide variability in physical inactivity - a 51-country survey. American Journal of Preventive Medicine, 34(6), 486-494. doi: 10.1016/j.amepre.2008.02.013 VIEW ITEM

Haase, A., Steptoe, A., Sallis, J. F., \& Wardle, J. (2004). Leisure-time physical activity in university students from 23 countries: associations with health beliefs, risk awareness, and national economic development. Preventive Medicine, 39(1), 182-190. doi: 10.1016/j.ypmed.2004.01.028 VIEW ITEM

Hallal, P. C., Victora, C. G., Azevedo, M. R., \& Wells, J. C. (2006). Adolescent physical activity and health: a systematic review. Sports Medicine 36(12), 1019-1030. doi: 10.2165/00007256-200636120-00003 VIEW ITEM

Hardman, K. (2008). Physical education in schools: a global perspective. Kinesiology, 40(1), 5-28. VIEW ITEM

Janssen, P. (2001). Lactate threshold training. Champaign, IL: Human Kinetics.

Kim, H. Y., Frongill, E. A., Han, S. S., Oh, S. Y., Kim, W. K., Jang, Y. A., \& et al. (2003). Academic performance of Korean children is associated with dietary behaviours and physical status. Asia Pacific Journal of Clinical Nutrition, 12(2), 186-192. VIEW ITEM

Madell, D., \& Muncer, S. (2004). Gender differences in the use of the internet by English secondary school children. Social Psychology of Education, 7(2), 229-251. doi: 10.1023/B:SPOE.0000018552.85903.4d VIEW ITEM

Malina, R. M., Bouchard, C., \& Bar-Or, O. (2004). Growth, maturation, and physical activity. (2nd edition) Champaign, IL: Human Kinetics Publishers.

Martínez-Vizcaíno, V., \& Sánchez-López, M. (2008). Relationship between physical activity and physical fitness in children and adolescents. Revista Espanola Cardiologia, 61(2), 108-111. doi: 10.1016/S1885-5857(08)60084-5 VIEW ITEM

Meredith, M. D., \& Welk, G. J. (2010). (Eds.). Fitnessgram/activitygram Test Administration Manual (updated 4th edition). Dallas: Human Kinetics.

Moreno, J. A., Cervelló, E., \& Moreno, R. (2008). The importance of physical-sport practice and gender in physical self-concept from 9 up to 23 years. International Journal of Clinical Health Psychology, 8(1), 171-183. VIEW ITEM

Ng, S. W., Norton, E. C., \& Popkin, B. M. (2009). Why have physical activity levels declined among Chinese adults? Findings from the 1991-2006 China health and nutrition surveys. Social Science and Medicine, 68(7), 1305-1314. doi: 10.1016/j.socscimed.2009.01.035 VIEW ITEM

Pori, M., Pori, P., Pistotnik, B., Dolenec, A., Tomažin, K., Štirn, I., \& et al. (2013). Športna rekreacija [Sports recreation]. Ljubljana: Športna unija Slovenije.

Ramsbottom, R., Brewer, J., \& Williams, C. (1988). A progressive shuttle run test to estimate maximal oxygen uptake. British Journal of Sports Medicine, 22(4), 141-144. doi: 10.1136/bjsm.22.4.141 VIEW ITEM 
Silvester LIPOŠEK, Jurij PLANINŠEC, Bojan LESKOŠEK, Aleksander PAJTLER: PHYSICAL ACTIVITY OF UNIVERSITY STUDENTS ..., 89-104

Renfrow, M. S., Caputo, J. L., Otto, S. M., Farley, R. F., \& Eveland-Sayers, B. M. (2011). The relationship between sports participation and health-related physical fitness in middle school and high school students. Physical Educator, 68(3), 118-123. VIEW ITEM

Sallis, J. F., McKenzie, T. L., Kolody, B., Lewis, M., Marshall, S., \& Rosengard, P. (1999). Effects of health-related physical education on academic achievement: project SPARK. Research Quarterly for Exercise and Sport, 70(2), 127-134. doi: 10.1080/02701367.1999.10608030 VIEW ITEM

Shriver, L. H., Harrist, A. W., Hubbs-Tait, L., Topham, G., Page, M., \& Barrett, A. (2011). Weight status, physical activity, and fitness among third-grade rural children. Journal of School Health, 81(9), 536-544. doi: 10.1111/j.1746-1561.2011.00624.x VIEW ITEM

Sibley, B. A., \& Etnier, J. L. (2003). The relationship between physical activity and cognition in children: A meta-analysis. Pediatric Exercise Science, 15(3), 243-256. doi: 10.1123/pes.15.3.243 VIEW ITEM

Strel, J., Ambrožič, F., Kondrič, M., Kovač, M., Leskošek, B., Štihec, J., et al. (1996). Športnovzgojni karton. Ljubljana: Ministrstvo za šolstvo in šport.

Topend Sports. (2016). Eurofit Fitness Testing Battery. Retrieved from http://www.topendsports.com/testing/eurofit.htm.

Tremblay, M. S., Inman, J. W., \& Williams, D. (2000). The relationship between physical activity, self-esteem, and academic achievement in 12-year-old children. Pediatric Exercise Science, 12, 312-323. doi: 10.1123/pes.12.3.312 VIEW ITEM

Trost, S. (2016). Active education: Physical education, physical activity, and academic performance. Retrieved from http://activelivingresearch.org/sites/default/files/ALR Brief ActiveEducation Summer2009.pdf.

Trudeau, F., \& Shephard, R. J. (2008). Physical education, school physical activity, school sports and academic performance. International Journal of Behavioral Nutrition and Physical Activity, 5, 10. doi: 10.1186/1479-5868-5-10 VIEW ITEM

Warburton, D. E., Nicol, C. W., \& Bredin, S. S. (2006). Health benefits of physical activity: the evidence. Canadian Medical Association Journal, 174(6), 801-809. doi: 10.1503/ cmaj.051351 VIEW ITEM

Weiss, M. R., \& Williams, L. (2004). The why of youth sport involvement: a developmental perspective on motivation processes. In M.R. Weiss (Ed.), Developmental sport and exercise psychology: A lifespan perspective (pp 223-268). Morgantown, WV: Fitness Information Technology.

Westerståhl, M., Barnekow-Berkvist, M., Hedberg, G., \& Jansson, E. (2003). Secular trends in sports: participation and attitudes among adolescents in Sweden from 1974 to 1995. Acta Paediatrica, 92(5), 602-609. doi: 10.1111/j.1651-2227.2003.tb02514.x VIEW ITEM

World Health Organization. (2004). Global strategy on diet, physical activity and health. Geneva, 4. Retrieved from https://www.who.int/dietphysicalactivity/strategy/eb11344/ strategy english web.pdf

World Health Organization. (2016). Physical activity. Levels of insufficient physical activity. Retrieved from http://www.who.int/mediacentre/factsheets/fs385/en/. 